\title{
Ferrocene-based Lewis acids and Lewis pairs: Synthesis and structural characterization
}

\author{
PAGIDI SUDHAKAR and PAKKIRISAMY THILAGAR* \\ Department of Inorganic and Physical Chemistry, Indian Institute of Science, Bangalore 560012 , India \\ e-mail: thilagar@ipc.iisc.ernet.in
}

MS received 7 September 2012; revised 25 October 2012; accepted 2 November 2012

\begin{abstract}
Optically active Lewis acids and Lewis pairs were synthesized and characterized by multinuclear NMR, UV/Vis spectroscopy and elemental analysis. Optical rotation measurements were carried out and the absolute configuration of the new chiral molecules confirmed by single crystal X-ray diffraction.
\end{abstract}

Keywords. Ferrocene/Lewis acid; optical rotation; frustrated Lewis pairs; organoborane.

\section{Introduction}

The design and synthesis of molecules containing non-interacting Lewis base and Lewis acid groups [Frustrated Lewis pairs (FLP's)] have received intense attention due to their potential applications in the area of molecular catalysis. ${ }^{1-3}$ For example, Stephen's and co-workers have demonstrated that the unquenched Lewis acidity and Lewis basicity of $\left(\mathrm{C}_{6} \mathrm{H}_{2} \mathrm{Me}\right)_{2} \mathrm{PH}\left(\mathrm{C}_{6} \mathrm{~F}_{4}\right) \mathrm{BF}\left(\mathrm{C}_{6} \mathrm{~F}_{5}\right)_{2}$ reversibly activate molecular hydrogen, in the absence of transition metals. ${ }^{2}$ FLP's can also be used to activate C-H, B-H and $\mathrm{N}-\mathrm{H}$ bonds. Erker and co-workers have demonstrated the reversible activation of $\mathrm{H}_{2}$ by metallocene based FLPs. ${ }^{3}$ Surprisingly, there is no report on the synthesis of enantiomerically pure FLP's, which would be very important for chiral organic transformations. ${ }^{1-3}$

Lewis acidic organoboranes play key role both as reagents and catalysts in asymmetric organic synthesis. $^{4-9}$ The rigid three-dimensional structure and inherent planar chirality of 1,2-disubstituted ferrocenes bearing non-identical atoms provide excellent chiral environment for enantioselective synthesis. ${ }^{9,10}$ Several planar chiral ferrocene based phosphines and amines are known and their catalytic activity in the presence of transition metals is well documented. ${ }^{10}$ Piers, ${ }^{8}$ Wagner ${ }^{11}$ and Aldridge ${ }^{12}$ have independently prepared various ferrocenylboranes and studied their applications in catalysis and as anion sensors. Jakle et al. ${ }^{9,13}$ have prepared verious ferrocenylboranes and studied their applications in anion binding as well as

*For correspondence in chiral synthesis. It is noteworthy to mention that Aldridge and co-workers recently have devised a simple route for the synthesis of planar chiral frustrated Lewis pairs (PCFLP's) from 1,1'-dibromoferrocene, but the final products were in racemic form. ${ }^{14 a}$ Instead, use of chiral ferrocenyl sulphoxide can be visualized as a precursor for optically pure isomers both 1-phosphino-2-borylferrocenes $\left(\mathrm{S}_{\mathrm{P}}\right)$ and 2-phosphino1-borylferrocenes $\left(R_{P}\right)$. We anticipate that the preparation of PCFLP's could open up a new entry into enantioselective catalysts and also that the reversible redox chemistry at the metal centre can be used to fine tune the activity of the PCFLP's. While the work was under progress in our lab ${ }^{14 b-d}$ Siewert and coworkers ${ }^{14 e}$ have independently reported the syntheses of homochiral Sp-1,2-fc $\left(\mathrm{PPh}_{2}\right)\left(\mathrm{BMes}_{2}\right)$ using ferrocene sulphoxide as a precursor, but they have not explored the possibility of synthesis of $\mathrm{Rp}-1,2-\mathrm{fc})\left(\mathrm{BMes}_{2}\right)\left(\mathrm{PPh}_{2}\right)$ from the same precursor. Prior to the report of Siewert et al., the preliminary accounts of our work reported in this manuscript have been presented in one international and two national conferences. ${ }^{14 \mathrm{~b}-\mathrm{d}}$ In this communication, we report our independent results on the synthesis and characterization of both 1-phosphino-2borylferrocene $\left(\mathrm{S}_{\mathrm{P}}\right)$ and 2-phosphino-1-borylferrocene $\left(\mathrm{R}_{\mathrm{P}}\right)$ from single precursor chiral ferrocenylsulphoxide.

\section{Experimental}

\subsection{General procedure}

$n$-Butyl lithium, $t$-butyl lithium (1.7M in hexanes), bis-mesitylfluroborane and $\mathrm{PPh}_{2} \mathrm{Cl} \&$ were purchased 
from Aldrich. Caution! Lithium reagents and $\mathrm{Ph}_{2} \mathrm{PCl}$ are toxic and highly corrosive and should be handled appropriately with great care. All reactions and manipulations were carried out under an atmosphere of prepurified nitrogen using Schlenk techniques. Due to the unpleasant odour of $\mathrm{Ph}_{2} \mathrm{PCl}$, most of the manipulations were carried out in a well-ventilated fume hood. Thin-layer chromatography (TLC) analyses were carried out on pre-coated silica gel plates (Merck), and spots were visualized by UV irradiation. Column chromatography was performed on glass columns loaded with silica gel. THF and hexane were distilled from sodium/benzophenone. Chlorinated solvents were stirred for $24 \mathrm{~h}$ over anhydrous $\mathrm{CaH}_{2}$, then degassed via several freeze pump thaw cycles and stored over $3 \AA$ molecular sieves. $400 \mathrm{MHz}^{1} \mathrm{H}$ NMR, $100.613 \mathrm{MHz}$ ${ }^{13} \mathrm{C}$ NMR, $128.378 \mathrm{MHz},{ }^{11} \mathrm{~B}$ NMR and $161.976 \mathrm{MHz}$ ${ }^{31} \mathrm{P}$ NMR spectra were recorded on a Bruker $400 \mathrm{MHz}$ NMR spectrometer. Solution ${ }^{1} \mathrm{H}$ and ${ }^{13} \mathrm{C}$ NMR spectra were referenced internally to the solvent signals. ${ }^{11} \mathrm{~B}$ NMR spectra to $\mathrm{BF}_{3} \cdot \mathrm{OEt}_{2}(\delta=0)$ in $\mathrm{C}_{6} \mathrm{D}_{6}$. Mass spectral studies were carried out using a QTOF micro mass spectrometer or Bruker Daltonics Esquire 6000 plus mass spectrometer with ESI-MS mode analysis. The melting point was determined in open capillary using an ANALAB melting-point apparatus. UV-visible absorption data were acquired on a UV-vis/NIR perkin Elmer Lambda 750 spectrophotometer. Solutions were prepared using a microbalance $( \pm 0.1 \mathrm{mg})$ and volumetric glassware and then charged into quartz cuvettes with sealing screw caps. Optical rotation analysis was performed on JASCO p-1020 III polarimeter, using a tungsten-halogen light source operating at $\lambda=589 \mathrm{~nm}$. CCDC 823721-823724 contain the supplementary crystallographic data for this paper. These data can be obtained free of charge from The Cambridge Crystallographic Data Centre via www.ccdc.cam.ac.uk/data_request/cif.

\subsection{Preparation of $\left(2\left(S_{P}, S_{S}\right)\right)$}

To a solution of Ferrocenyl-p-tolylsulphoxide $(1.00 \mathrm{~g}$, $3.05 \mathrm{mmol})$ in THF $(30 \mathrm{~mL})$ at $-78^{\circ} \mathrm{C}$ was added drop-wise LDA $(2 \mathrm{~mL}, 0.34 \mathrm{mmol})$ and the reaction mixture was stirred for $1 \mathrm{~h}$. A solution of dimesityl fluoroborane $(1 \mathrm{~g}, 4.06 \mathrm{mmol})$ in THF $(4 \mathrm{~mL})$ was added. The mixture was allowed to warm up to room temperature and kept stirring for an additional $6 \mathrm{~h}$. After standard aqueous work-up, the crude product was purified by column chromatography (EtOAc-hexane 1:3 ratio) to obtain orange crystal. Yield: $0.6 \mathrm{~g}, 80 \%[\alpha]_{\mathrm{D}}^{24}=$ -676. $1 \mathrm{H} \mathrm{NMR} \mathrm{(400} \mathrm{MHz,} \mathrm{CDCl}_{3}, 25^{\circ} \mathrm{C}, \delta$ (ppm)): $2.24(\mathrm{~s}, 6 \mathrm{H}), 2.32(\mathrm{~s}, 12 \mathrm{H}), 2.419(\mathrm{~s}, 3 \mathrm{H}), 4.12(\mathrm{~s}, 5 \mathrm{H})$, $4.43(\mathrm{~m}, 1 \mathrm{H}), 4.62(\mathrm{~m}, 2 \mathrm{H}), 6.74(\mathrm{~s}, 4 \mathrm{H}), 7.24(\mathrm{~s}, 2 \mathrm{H})$, 7.56-7.54 (d, 2H). ${ }^{13} \mathrm{C} \mathrm{NMR}\left(100 \mathrm{MHz}, \mathrm{CDCl}_{3}, 25^{\circ} \mathrm{C}, \delta\right.$ (ppm)), 21.54, 21.95, 25.25, 71.59, 72.33, 73.34, 81.01, $101.10,125.65,129.4,129.6,137.9,140.3,140.6$, 141.4, 143.2: ESI Mass Spectrometry: Mcalc $=572.2$ : found: $595.0[\mathrm{M}+\mathrm{Na}]^{+} ; 611.0[\mathrm{M}+\mathrm{K}]^{+}$, (UV-Vis) $\left(\mathrm{CH}_{2} \mathrm{Cl}_{2}, 1.001 \times 10-5 \mathrm{M}\right): \lambda \max =496 \mathrm{~nm}(\varepsilon=$ $2.6 \times 103)$. Elemental analysis for $\mathrm{C}_{37} \mathrm{H}_{52} \mathrm{BFeOS}$ : $\mathrm{C}$, 72.67; $\mathrm{H}, 8.57$, found $\mathrm{C}, 72.12 ; \mathrm{H}, 8.25$

\subsection{Preparation of $\left(3\left(S_{P}, S_{S}\right)\right)$}

To a solution of $\mathbf{2}\left(\mathbf{S}_{\mathbf{P}}, \mathbf{S}_{\mathbf{S}}\right)$ in THF was added distilled water $(0.1 \mathrm{~mL})$. The reaction mixture was stirred for $6 \mathrm{~h}$ at room temperature. The product was extracted with diethyl ether and volatiles were removed in vacuo to obtain desired product. Yield: $60 \% .[\alpha]_{\mathrm{D}}^{24}=463$, ${ }^{1} \mathrm{H}$ NMR $\left(400 \mathrm{MHz}, \mathrm{CDCl}_{3}, 25^{\circ} \mathrm{C}, \delta \mathrm{ppm}\right): 2.01$ (s, $1 \mathrm{H}), 2.20(\mathrm{~s}, 3 \mathrm{H}), 2.26(\mathrm{~s}, 8 \mathrm{H}), 4.09(\mathrm{~m}, 1 \mathrm{H}), 4.45$ $(\mathrm{s}, 5 \mathrm{H}), 4.52(\mathrm{~d}, 1 \mathrm{H}), 4.99(\mathrm{~m}, 1 \mathrm{H}), 6.77(\mathrm{~d}, 2 \mathrm{H})$, $7.17(\mathrm{~m}, 2 \mathrm{H}), 7.41(\mathrm{~d}, 2 \mathrm{H}) .10 .74(\mathrm{~s}, 1 \mathrm{H}){ }^{13} \mathrm{C} \mathrm{NMR}$ $\left(100 \mathrm{MHz}, \mathrm{CDCl}_{3}, 25^{\circ} \mathrm{C}\right) \delta 21.67,21.76,71.27,73.29$, 74.76, 79.59, 100.25, 124.64, 127.60, 130.13, 137.76, 141.34, 142.17. ${ }^{11} \mathrm{~B}$ NMR $\left(160 \mathrm{MHz}, \mathrm{CDCl}_{3}, 25^{\circ} \mathrm{C}\right)$ $\delta$ : 46.21, ESI Mass Spectrometry: Mcalc: 470.1; found: $507.4[\mathrm{M}+\mathrm{OMe}+\mathrm{H}]$; . Elemental analysis for $\mathrm{C}_{26} \mathrm{H}_{27} \mathrm{BFeO}_{2} \mathrm{~S}$; C, 66.41; $\mathrm{H}, 5.79$; found $\mathrm{C}$, 66.10; $\mathrm{H}, 5.35$. UV-Vis $\left(\mathrm{CH}_{2} \mathrm{Cl}_{2}, 1.001 \times 10-5 \mathrm{M}\right): \lambda \max =$ $438 \mathrm{~nm}\left(\varepsilon=1.0 \times 10^{2}\right)$.

\subsection{Preparation of $\left(\mathbf{4}\left(\boldsymbol{S}_{P}\right)\right)$}

To a solution of $\mathbf{2}\left(\mathbf{S}_{\mathbf{P}}, \mathbf{S}_{\mathbf{S}}\right)(100 \mu \mathrm{g}, 0.17 \mathrm{mmol})$ in THF $(10 \mathrm{~mL})$ at $-78^{\circ} \mathrm{C}$ was added $t$-BuLi $(77 \mu \mathrm{L}$, $0.18 \mathrm{mmol}$ ) and the reaction mixture stirred for $1 \mathrm{~h}$. Chlorodiphenylphosphine ( $33 \mu \mathrm{L}, 0.64 \mathrm{mmol})$ was added and the reaction mixture was allowed to warm up to room temperature. The reaction mixture was kept stirring overnight. Volatiles were removed in vacuo to yield crude product, which was purified by column chromatography (EtOAc-hexane) to give red solid. Yield: $10 \mathrm{mg}, 10 \% .[\alpha]_{\mathrm{D}}^{21}=-694.92$. ${ }^{1} \mathrm{H}$ NMR $\left(400 \mathrm{MHz}, \mathrm{CDCl}_{3}, 25^{\circ} \mathrm{C}, \delta \mathrm{ppm}\right) 2.21$ (s, $12 \mathrm{H}), 2.27(\mathrm{~s}, 3 \mathrm{H}), 2.38(\mathrm{~s}, 3 \mathrm{H}), 4.07(\mathrm{~s}, 1 \mathrm{H})$, $4.18(\mathrm{~s}, 5 \mathrm{H}), 4.26(\mathrm{~s}, 1 \mathrm{H}), 4.66(\mathrm{~m}, 1 \mathrm{H}), 6.59(\mathrm{~s}$, $3 \mathrm{H}), 6.64(\mathrm{~d}, 1 \mathrm{H}), 6.81(\mathrm{~m}, 3 \mathrm{H}), 7.09(\mathrm{t}, 2 \mathrm{H})$, $7.19(\mathrm{~m}, 1 \mathrm{H}), 7.32(\mathrm{~m}, 4 \mathrm{H}),{ }^{13} \mathrm{C} \operatorname{NMR}(100 \mathrm{MHz}$, $\mathrm{CDCl}_{3}, 25^{\circ} \mathrm{C}: 21.36,25.15,30.42,70.16,73.45,79.13$, $83.79,88.86,89.04,133.67,133.89,134.72,134.93$, 137.47, 139.86, 140.08, 143.81, ${ }^{31} \mathrm{P}$ NMR $(160 \mathrm{MHz}$, $\left.\mathrm{CDCl}_{3}, 25^{\circ} \mathrm{C} \delta \mathrm{ppm}\right):-21.5$, ESI Mass Spectrometry: 
Mcalc $=618.3$, found: $619[\mathrm{M}+\mathrm{H}]^{+} ; 641[\mathrm{M}+\mathrm{Na}]^{+}$; $656.9[\mathrm{M}+\mathrm{K}]^{+}$, UV-Vis $\left(\mathrm{CH}_{2} \mathrm{Cl}_{2}, 1.001 \times 10^{-5} \mathrm{M}\right)$ : $\lambda \max =506 \mathrm{~nm}\left(\varepsilon=1.2 \times 10^{3}\right)$. Elemental analysis for $\mathrm{C}_{41} \mathrm{H}_{52} \mathrm{BFeP}$ calcd C, 76.65; H, 8.16; found C, 76.22; $\mathrm{H}, 7.98$.

\subsection{Preparation of $\left(5\left(S_{P}, S_{S}\right)\right)$}

To a solution of Ferrocenyl-p-tolylsulphoxide (1.0 g, $3.05 \mathrm{mmol})$ in freshly distilled THF $(30 \mathrm{ml})$, was added LDA $(1.7 \mathrm{ml}, 3.36 \mathrm{mmol})$ at $-78^{\circ} \mathrm{C}$. The reaction mixture was stirred at $-78^{\circ} \mathrm{C}$ for $1 \mathrm{~h}$ and $\mathrm{PPh}_{2} \mathrm{Cl}$ $(600 \mu \mathrm{l}, 3.1 \mathrm{mmol})$ was added. The resulting solution was warmed to room temperature, stirred for $6 \mathrm{~h}$ and quenched with water $(5 \mathrm{ml})$. The organic layer was separated and the aqueous layer was extracted with diethyl ether $(2 \times 20 \mathrm{ml})$. The combined organic extracts were washed with brine $(10 \mathrm{ml})$ and dried over anhydrous $\mathrm{Na}_{2} \mathrm{SO}_{4}$. The solvent was evaporated under reduced pressure and the residue was purified by column chromatography on silica gel (60-120 mesh) using petether/diethyl ether (1:1) as eluent to obtain (S,S)-2-
(Diphenylphosphino)-1-( $p$-tolylsulfinyl)ferrocene as a yellow solid in $27 \%$ yield. ${ }^{1} \mathrm{H}-\mathrm{NMR}\left(400 \mathrm{MHz}, \mathrm{CDCl}_{3}\right.$, $\left.25^{\circ} \mathrm{C}\right) \delta 2.35(\mathrm{~s}, 3 \mathrm{H}), 4.05(\mathrm{~m}, 5 \mathrm{H}), 4.30(\mathrm{~s}, 1 \mathrm{H}), 4.50$ $(\mathrm{d}, 1 \mathrm{H}), 4.51(\mathrm{~d}, 1 \mathrm{H}), 7.17(\mathrm{~s}, 2 \mathrm{H}), 7.37(\mathrm{~m}, 6 \mathrm{H})$, 7.74-7.57 (m, 6H). ${ }^{31} \mathrm{P} \mathrm{NMR}\left(160 \mathrm{MHz}, \mathrm{CDCl}_{3}, 25^{\circ} \mathrm{C}\right)$ : $\delta-24$.

\subsection{Preparation of $\left(\mathbf{4}\left(\boldsymbol{R}_{\boldsymbol{P}}\right)\right)$}

To a solution of $\mathbf{5}\left(\mathbf{S}_{\mathbf{P}}, \mathbf{S}_{\mathbf{S}}\right)(0.09 \mathrm{~g}, 0.17 \mathrm{mmol})$ in THF $(10 \mathrm{~mL})$ at $-78^{\circ} \mathrm{C}$ was added $t$-BuLi $(77,0.18 \mathrm{mmol})$ and the reaction mixture was stirred for $2 \mathrm{~h}$. Dimesityl fluoroborane $(33 \mu \mathrm{L}, 0.64 \mathrm{mmol})$ was then added and the reaction mixture was warmed to room temperature and stirred for overnight. Volatiles were removed in vacuo to yield crude product which was purified by column chromatography (EtOAc-hexane) to give red solid. Yield: $20 \%$. $[\alpha]_{\mathrm{D}}^{21}=674.9 .{ }^{1} \mathrm{H}$ NMR $(400 \mathrm{MHz}$, $\left.\mathrm{CDCl}_{3}, 25^{\circ} \mathrm{C}, \delta \mathrm{ppm}\right) 2.22$ (s, 12H), 2.26 (s, 3H), 2.39 $(\mathrm{s}, 3 \mathrm{H}), 4.10(\mathrm{~s}, 1 \mathrm{H}), 4.20(\mathrm{~s}, 5 \mathrm{H}), 4.25(\mathrm{~s}, 1 \mathrm{H}), 4.67$ $(\mathrm{m}, 1 \mathrm{H}), 6.59(\mathrm{~s}, 3 \mathrm{H}), 6.65(\mathrm{~d}, 1 \mathrm{H}), 6.80(\mathrm{~m}, 3 \mathrm{H})$, $7.10(\mathrm{t}, 2 \mathrm{H}), 7.20(\mathrm{~m}, 1 \mathrm{H}), 7.31(\mathrm{~m}, 4 \mathrm{H}) .{ }^{13} \mathrm{C} \mathrm{NMR}$

Table 1. Details of X-ray crystal structure analyses of complexes $2\left(\mathbf{S}_{\mathbf{P}}, \mathbf{S}_{\mathbf{S}}\right), \mathbf{3}\left(\mathbf{S}_{\mathbf{P}}, \mathbf{S}_{\mathbf{S}}\right), \mathbf{4}\left(\mathbf{S}_{\mathbf{P}}\right)$ and $\mathbf{5}\left(\mathbf{S}_{\mathbf{P}}, \mathbf{S}_{\mathbf{S}}\right)$.

\begin{tabular}{|c|c|c|c|c|}
\hline Compound & $2\left(S_{P}, S_{S}\right)$ & $\mathbf{3}\left(\mathbf{S}_{\mathbf{P}}, \mathbf{S}_{\mathbf{S}}\right)$ & $4\left(S_{P}\right)$ & $\mathbf{5}\left(\mathbf{S}_{\mathbf{P}}, \mathbf{S}_{\mathbf{S}}\right)$ \\
\hline Empirical formula & $\mathrm{C}_{35} \mathrm{H}_{37} \mathrm{BFeOS}$ & $\mathrm{C}_{26} \mathrm{H}_{27} \mathrm{BFeO}_{2} \mathrm{~S}$ & $\mathrm{C}_{40} \mathrm{H}_{40} \mathrm{BFeP}$ & $\mathrm{C}_{29} \mathrm{H}_{25} \mathrm{FeOPS}$ \\
\hline MW & 572.39 & 470.21 & 618.37 & 508.39 \\
\hline$T, K$ & $273(2)$ & $273(2)$ & $363(2)$ & $293(2)$ \\
\hline Wavelength, $\AA$ & 0.71073 & 0.71073 & 0.71073 & 0.71073 \\
\hline Crystal system & Orthorhombic & Monoclinic & Orthorhombic & Monoclinic \\
\hline Space group & $\mathrm{P} 2{ }_{1}{ }_{1} 2_{1}$ & $\mathrm{P} 2_{1}$ & $\mathrm{P} 2{ }_{1}{ }_{1} 2_{1}$ & $\mathrm{P} 21$ \\
\hline$a, \AA$ & $9.360(2)$ & $7.433(3)$ & $13.8055(17)$ & $7.727(5)$ \\
\hline$b, \AA$ & $11.884(3)$ & $9.196(3)$ & $14.9786(18)$ & $14.233(8)$ \\
\hline$c, \AA$ & $25.331(6)$ & 17.092 & $15.4878(19)$ & $10.969(7)$ \\
\hline $\mathrm{V}, \AA^{3}$ & $2817.8(11)$ & $1166.8(7)$ & $3202.7(7)$ & $1196.5(12)$ \\
\hline$Z$ & 4 & 2 & 3 & 2 \\
\hline$\rho_{\text {calc }}, \mathrm{g} \mathrm{cm}^{-3}$ & 1.349 & 1.338 & 1.282 & 2.386 \\
\hline$\mu(\mathrm{Mo} / \mathrm{Cu} \mathrm{K} \alpha), \mathrm{mm}^{-1}$ & 0.637 & 0.756 & 0.548 & 0.861 \\
\hline Crystal size, $\mathrm{mm}$ & $0.30 \times 0.20 \times 0.20$ & $0.25 \times 0.22 \times 0.20$ & $0.20 \times 0.20 \times 0.20$ & $0.15 \times 0.15 \times 0.15$ \\
\hline$\theta$ range, deg & 1.89 to 28.11 & 2.39 to 28.07 & 1.89 to 28.01 & 1.87 to $26.37 \mathrm{deg}$ \\
\hline Limiting indices & $\begin{array}{l}-12<=\mathrm{h}<=12 \\
-15<=\mathrm{k}<=15 \\
-33<=\mathrm{l}<=33\end{array}$ & $\begin{array}{c}-9<=\mathrm{h}<=9 \\
-12<=\mathrm{k}<=11 \\
-22<=\mathrm{l}<=22\end{array}$ & $\begin{array}{l}-18<=\mathrm{h}<=18 \\
-19<=\mathrm{k}<=19 \\
-20<=\mathrm{l}<=20\end{array}$ & $\begin{array}{c}-9<=\mathrm{h}<=9 \\
-17<=\mathrm{k}<=17 \\
-13<=\mathrm{l}<=13\end{array}$ \\
\hline Reflns collected & 32711 & 13432 & 37168 & 12595 \\
\hline Independent reflns & $6740[\mathrm{R}$ (int) $=0.0579]$ & $5416[\mathrm{R}$ (int) $=0.0237]$ & $7646[\mathrm{R}(\mathrm{int})=0.0566]$ & $4879[\mathrm{R}(\mathrm{int})=0.0853]$ \\
\hline Absorption correction & SADABS & SADABS & SADABS & SADABS \\
\hline data/restraints/parameters & $6740 / 0 / 359$ & $5416 / 1 / 285$ & $7646 / 0 / 394$ & $4879 / 1 / 300$ \\
\hline Goodness-of-fit on $F^{2}$ & 0.981 & 1.059 & 1.016 & 0.959 \\
\hline Final $\mathrm{R}$ indices $[\mathrm{I}>2 \sigma(\mathrm{I})]^{[\mathrm{a}]}$ & $\begin{array}{c}\mathrm{R} 1=0.0339 \\
\mathrm{wR} 2=0.0700\end{array}$ & $\begin{array}{l}\mathrm{R} 1=0.0322, \\
\mathrm{wR} 2=0.0832\end{array}$ & $\begin{array}{c}\mathrm{R} 1=0.0379 \\
\mathrm{wR} 2=0.0739\end{array}$ & $\begin{array}{l}\mathrm{R} 1=0.0696, \\
\mathrm{wR} 2=0.1372\end{array}$ \\
\hline $\mathrm{R}$ indices (all data) ${ }^{[\mathrm{a}]}$ & $\begin{array}{c}\mathrm{R} 1=0.0453 \\
\mathrm{wR} 2=0.0719\end{array}$ & $\begin{array}{l}\mathrm{R} 1=0.0338, \\
\mathrm{wR} 2=0.0844\end{array}$ & $\begin{array}{c}\mathrm{R} 1=0.0536 \\
\mathrm{wR} 2=0.0778\end{array}$ & $\begin{array}{c}\mathrm{R} 1=0.1409, \\
\mathrm{wR} 2=0.1625\end{array}$ \\
\hline Peak $_{\max } / h_{\text {hole }} \min \left(\mathrm{e} \AA^{-3}\right)$ & 0.497 and -0.250 & 0.232 and -0.325 & 0.469 and -0.251 & 0.667 and -0.315 \\
\hline Absolute structure parameter & $0.012(11)$ & $0.075(11)$ & $0.038(11)$ & $0.07(3)$ \\
\hline
\end{tabular}

${ }^{[\mathrm{a}]} R 1=\Sigma|| \mathrm{F}_{\mathrm{o}}|-| \mathrm{F}_{\mathrm{c}}|| / \Sigma\left|\mathrm{F}_{\mathrm{o}}\right| ; w R 2=\left\{\Sigma\left[\mathrm{w}\left(\mathrm{F}_{\mathrm{o}}^{2}-\mathrm{F}_{\mathrm{c}}^{2}\right)^{2}\right] / \Sigma\left[\mathrm{w}\left(\mathrm{F}_{\mathrm{o}}^{2}\right)^{2}\right]\right\}^{1 / 2}$ 
$\left(100 \mathrm{MHz}, \mathrm{CDCl}_{3}, 25^{\circ} \mathrm{C}\right) \delta 21.35,25.16,30.41,70.14$, $73.42,79.11,83.77,88.87,89.06,133.66,133.90$, $134.71,134.92,137.41,139.87,140.10,143.80 .{ }^{31} \mathrm{P}$ $\mathrm{NMR}\left(160 \mathrm{MHz}, \mathrm{CDCl}_{3}, 25^{\circ} \mathrm{C} \delta \mathrm{ppm}\right)-20.5$. ESI Mass Spectrometry: Mcalc $=618.37$, found: $619[\mathrm{M}+\mathrm{H}]^{+}$, $656.9[\mathrm{M}+\mathrm{K}]^{+}$, UV-Vis, $\left(\mathrm{CH}_{2} \mathrm{Cl}_{2}, 1.001 \times 10^{-5} \mathrm{M}\right)$ : $\lambda \max =506 \mathrm{~nm}\left(\varepsilon=1.2 \times 10^{3}\right)$. Elemental analysis for $\mathrm{C}_{41} \mathrm{H}_{52} \mathrm{BFeP}$ calcd $\mathrm{C}, 76.65 ; \mathrm{H}, 8.16$, found $\mathrm{C}$, 76.20; H, 8.0.

2.7 Structure determination of compounds $2\left(S_{P}, S_{S}\right)$, $\mathbf{3}\left(S_{P}, S_{S}\right), 4\left(S_{P}\right)$ and $5\left(S_{P}, S_{S}\right)$

Single-crystal X-ray diffraction studies were carried out with a Bruker SMART APEX diffractometer equipped with 3-axis goniometer. The crystals were kept under a steady flow of cold dinitrogen during the data collection. The details regarding the data collection and refinement for compounds $2\left(S_{P}, S_{S}\right), 3\left(S_{P}, S_{S}\right), 4\left(S_{P}\right)$ and $\mathbf{5}\left(\mathbf{S}_{\mathbf{P}}, \mathbf{S}_{\mathbf{S}}\right)$ are given in table 1 . The data were integrated using SAINT, and an empirical absorption correction was applied with SADABS. The structures were solved by direct methods and refined by full matrix least-squares on F2 using SHELXTL software. All the non-hydrogen atoms were refined with anisotropic displacement parameters, while the hydrogen atoms were refined isotropically on the positions calculated using a riding model.

\section{Results and discussion}

The synthetic strategy followed in the syntheses of compounds $2\left(\mathbf{S}_{\mathbf{P}}, \mathbf{S}_{\mathbf{S}}\right)-5$ is described in scheme 1 . The synthetic access to the chiral ferrocenylsulphoxide (1) was made possible by the principal studies of Kagan who converted stanylferrocene to $\mathbf{1}$ by the action of $\mathrm{n}$-BuLi followed by (S,S)-menthyl-ptolylsulphinate. ${ }^{10 \mathrm{e}, 10 \mathrm{~d}, 15}$ The second step of the process is the diastereo-selective ortholithiation of 1 by LDA at $-78^{\circ} \mathrm{C}$ in THF and followed by quenching with $\mathrm{Mes}_{2} \mathrm{BF}$ gave $\mathbf{2}\left(\mathbf{S}_{\mathbf{P}}, \mathbf{S}_{\mathbf{S}}\right)$ in $80 \%$ yield after silica gel column purification (scheme 1). The ${ }^{1} \mathrm{H}$ and ${ }^{13} \mathrm{C}$ NMR spectra of $\mathbf{2}\left(\mathbf{S}_{\mathbf{P}}, \mathbf{S}_{\mathbf{S}}\right)$ are consistent with a 1,2-disubstituted ferrocene derivatives, and a resonance at $\delta=49 \mathrm{ppm}$ in the ${ }^{11} \mathrm{~B}$ NMR spectrum confirms the attachment of the $\mathrm{BMes}_{2}$ group. The ${ }^{11} \mathrm{~B}$ NMR signal is considerably upfield shifted compared to other triorganyl boranes (in general they resonate at $60-70 \mathrm{ppm}) .{ }^{8-13}$ This may be due to the interaction between the boron in $-\mathrm{BMes}_{2}$ unit and the oxygen of tolylsulphinate moiety. The absolute configuration of $\mathbf{2}\left(\mathbf{S}_{\mathbf{P}}, \mathbf{S}_{\mathbf{S}}\right)$ was assigned from the singlecrystal X-ray structure, which confirms diastereoselective ortho lithiation of $\mathbf{1}$ (figure 1a).

The molecular structure of $\mathbf{2}\left(\mathbf{S}_{\mathbf{P}}, \mathbf{S}_{\mathbf{S}}\right)$ also gives evidence for B-O (3.293 A) interaction (figure 1a). Such kind of interaction was first noted by Aldridge and co-workers (B-O, $3.304 \AA$ ). ${ }^{14}$ In contrast to the observation noted by Siewert et al., compound $2\left(\mathbf{S}_{\mathbf{P}}, \mathbf{S}_{\mathbf{S}}\right)$ is not stable at atmospheric conditions and prone to

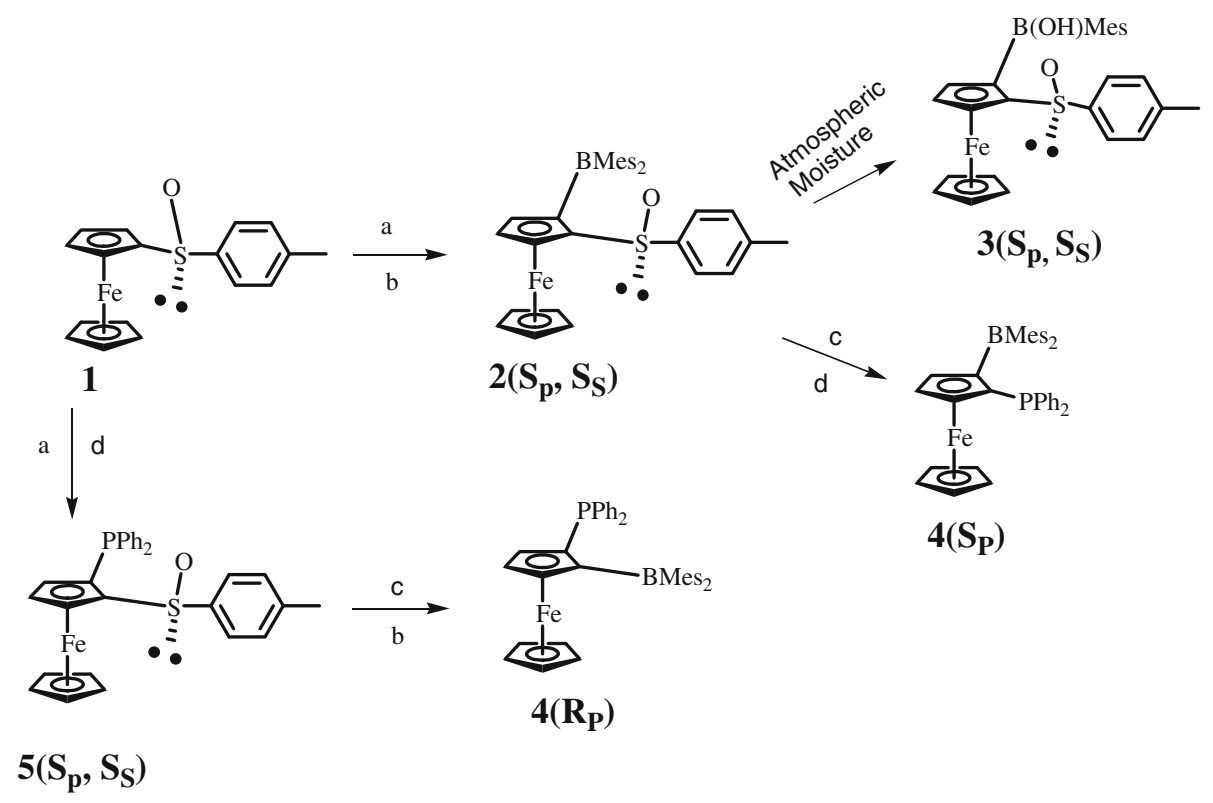

Scheme 1. Synthesis of compounds $2\left(\mathbf{S}_{\mathbf{P}}, \mathbf{S}_{\mathrm{S}}\right), \mathbf{3}\left(\mathbf{S}_{\mathbf{P}}, \mathbf{S}_{\mathrm{S}}\right), \mathbf{4}\left(\mathbf{S}_{\mathbf{P}}\right), \mathbf{4}\left(\mathbf{R}_{\mathrm{P}}\right)$ and $\mathbf{5}\left(\mathbf{S}_{\mathbf{P}}, \mathbf{S}_{\mathrm{S}}\right)$ (a) LDA, (b) $\mathrm{FBMes}_{2}$, (c) $t$-BuLi and (d) $\mathrm{ClPPh}_{2}$. 


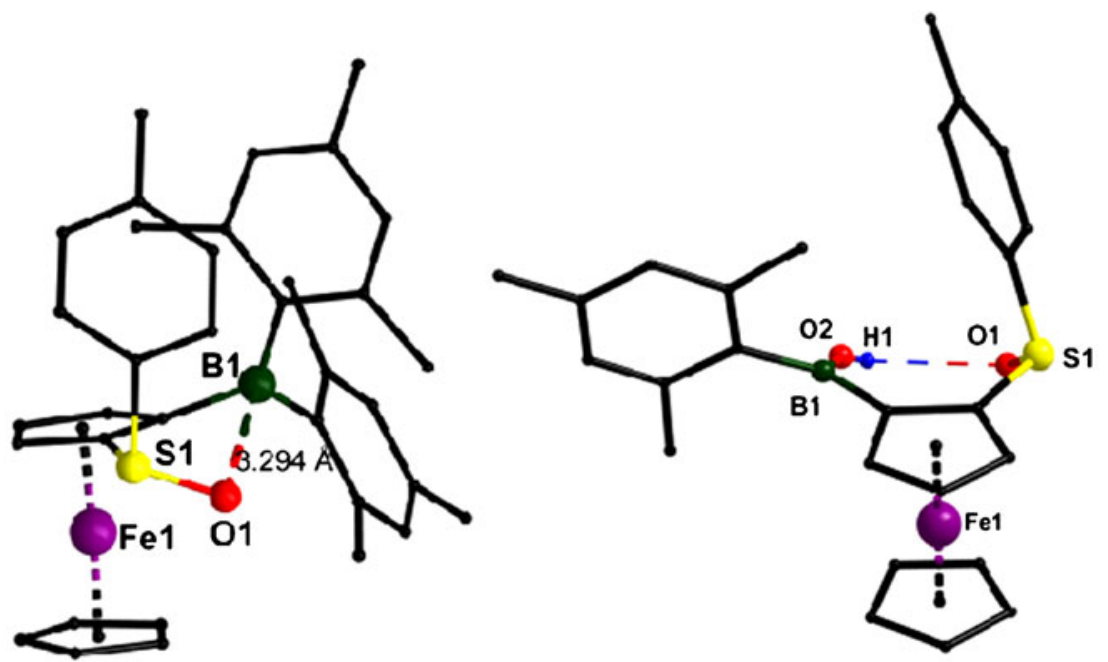

(a)

(b)

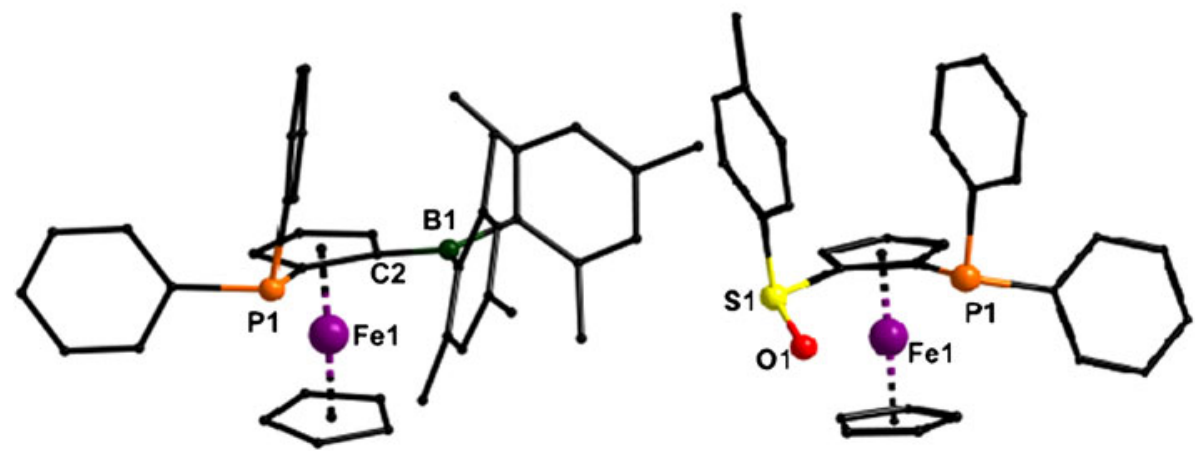

(c)

(d)

Figure 1. Molecular structures of (a) $2\left(\mathbf{S}_{\mathbf{P}}, \mathbf{S}_{\mathbf{S}}\right)$, (b) $3\left(\mathbf{S}_{\mathbf{P}}, \mathbf{S}_{\mathbf{S}}\right)$, (c) $4\left(\mathbf{S}_{\mathbf{P}}\right)$ and (d) $\mathbf{5}\left(\mathbf{S}_{\mathbf{P}}, \mathbf{S}_{\mathbf{S}}\right)$. All the hydrogen atoms are omitted for clarity. (a) Molecular structure of $2\left(\mathbf{S}_{\mathbf{P}}, \mathbf{S}_{\mathbf{S}}\right)$. Selected interatomic distances $[\AA]$ and angles $\left[{ }^{\circ}\right]$ : C(1)-B(1) 1.573(3), $\mathrm{C}(20)-\mathrm{B}(1)$ 1.584(3), C(11)-B(1) 1.589(3), S(1)-O(1) 1.5034(16), S(1)-C(2) 1.776(2), $\mathrm{S}(1)-\mathrm{C}(29) 1.804(2), \mathrm{O}(1)-\mathrm{S}(1)-\mathrm{C}(2) 107.67(9), \mathrm{O}(1)-\mathrm{S}(1)-\mathrm{C}(29)$ 105.45(1), C(2)-S(1)C(29) 99.16(9), C(1)-B(1)-C(20)119.60(2), C(1)-B(1)-C(11)116.83(2), C(20)-B(1)$\mathrm{C}(11) 122.01(2)$. (b) Molecular structure of $\mathbf{3}\left(\mathbf{S}_{\mathbf{P}}, \mathbf{S}_{\mathbf{S}}\right)$. Selected interatomic distances $[\AA]$ and angles $\left[{ }^{\circ}\right]: \mathrm{S}(1)-\mathrm{O}(2)$ 1.5058(17), S(1)-C(1) 1.770(2), S(1)-C(11) 1.799(2), $\mathrm{O}(1)-\mathrm{B}(1) \quad 1.351(3), \quad \mathrm{B}(1)-\mathrm{C}(18) \quad 1.575(3), \quad \mathrm{B}(1)-\mathrm{C}(2) \quad 1.577(3), \quad \mathrm{O}(2)-\mathrm{S}(1)-\mathrm{C}(1)$ 109.39(10), O(2)-S(1)-C(11) 106.10(1), C(1)-S(1)-C(11) 96.93(9), O(1)-B(1)-C(2) 118.68(2), O(1)-B(1)-C(2) 121.04(2), C(18)-B(1)-C(2) 120.28(2). (c) Molecular structure of $\mathbf{4}\left(\mathbf{S}_{\mathbf{P}}\right)$, selected interatomic distances $[\AA]$ and angles $\left[{ }^{\circ}\right] . \mathrm{P}(1)-\mathrm{C}(1) 1.824(2)$, $\mathrm{P}(1)-\mathrm{C}(11)$ 1.836(2), P(1)-C(17) 1.842(2), B(1)-C(2)1.557(3), B(1)-C(29)1.599(3), B(1)-C(23)1.599(3), C(1)-P(1)-C(11) 99.24(9), C(1)-P(1)-C(17) 99.26(1), C(11)$\mathrm{P}(1)-\mathrm{C}(17) 100.48(1), \quad \mathrm{C}(2)-\mathrm{B}(1)-(29) 114.14(2), \mathrm{C}(2)-\mathrm{B}(1)-\mathrm{C}(23) 126.31(2), \mathrm{C}(29)-$ $\mathrm{B}(1)-\mathrm{C}(23) 119.43(2)$. (d) Molecular structure of 5. Selected interatomic distances $[\AA]$ and angles [ ${ }^{\circ}$ ]: $\mathrm{S}(1)-\mathrm{O}(1) 1.470(5), \mathrm{S}(1)-\mathrm{C}(2) 1.780(8), \mathrm{S}(1)-\mathrm{C}(23) 1.781(6), \mathrm{P}(1)-\mathrm{C}(1)$ 1.784(6), P(1)-C(11) 1.819(7), P(1)-C(18) 1.836(6), O(1)-S(1)-C(2) 109.6(3), O(1)$\mathrm{S}(1)-\mathrm{C}(23)$ 106.8(3), C(2)-S(1)-C(23) 98.0(3), C(1)-P(1)-C(11) 100.4(3), C(1)-P(1)C(18) 101.9(3), C(11)-P(1)-C(18) 100.9(3).

hydrolysis. Over a period of a week it slowly underwent selective hydrolysis of one of the two B-Mes bonds by reacting with atmospheric moisture. The hydrolysed product was separated by using silica gel column chromatography technique and found to be compound
$\mathbf{3}\left(\mathbf{S}_{\mathbf{P}}, \mathbf{S}_{\mathbf{S}}\right)$. Later, compound $\mathbf{3}\left(\mathbf{S}_{\mathbf{P}}, \mathbf{S}_{\mathbf{S}}\right)$ was prepared by a different route (scheme 2).

When compound $\mathbf{2}\left(\mathbf{S}_{\mathbf{P}}, \mathbf{S}_{\mathbf{S}}\right)$ was allowed to react with one equivalent of water in THF $\mathbf{3}\left(\mathbf{S}_{\mathbf{P}}, \mathbf{S}_{\mathbf{S}}\right)$, the quantitative yield was obtained. The ${ }^{1} \mathrm{H}$ NMR spectrum 


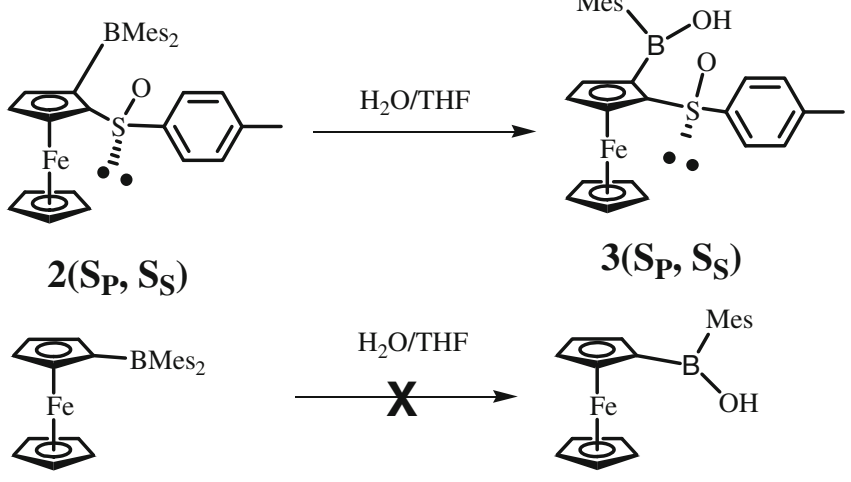

Scheme 2. Synthesis of $\mathbf{3}\left(\mathbf{S}_{\mathbf{P}}, \mathbf{S}_{\mathbf{S}}\right)$ from $2\left(\mathbf{S}_{\mathbf{P}}, \mathbf{S}_{\mathbf{S}}\right)$.

of $\mathbf{3}\left(\mathbf{S}_{\mathbf{P}}, \mathbf{S}_{\mathrm{S}}\right)$ shows three different resonances at 4.09 , 4.52 and $4.99 \mathrm{ppm}$ for substituted $\mathrm{Cp}$ and a single resonance for free $\mathrm{Cp}$ at $4.45 \mathrm{ppm}$. The hydrolysis might have occurred because of the intramolecular Tolyl-S$\mathrm{O}-\mathrm{B}$ interaction. The upfield shifted ${ }^{11} \mathrm{~B}$ resonance of $\mathbf{3}\left(\mathbf{S}_{\mathbf{P}}, \mathbf{S}_{\mathbf{S}}\right)$ (46.2 ppm) (see Supporting Information Figure S9) relative to the parent compound $2\left(\mathbf{S}_{\mathbf{P}}, \mathbf{S}_{\mathbf{S}}\right)$ (49 ppm) support the intramolecular interaction discussed vide-supra. In order to demonstrate the role of the $\mathrm{B}-\mathrm{O}$ interaction in the hydrolysis reaction, control experiment was designed in which $\mathrm{FcBMes}_{2}$, which lacks the Tolyl-S-O functionality, was tested for hydrolysis. FcBMes 2 was treated with 10 equiv of water for two days using THF as solvent (scheme 2). No B-C bond cleavage was observed and $\mathrm{FcBMes}_{2}$ was completely recovered. The molecular structure of $\mathbf{3}\left(\mathbf{S}_{\mathbf{P}}\right.$, $\mathbf{S}_{\mathbf{S}}$ ) is shown in figure 1. Although free rotation is possible at the boron centre (due to the absence of one bulky mesityl group), we observed only one isomer. This might be due to the strong intramolecular $\mathrm{OH}-\mathrm{O}(1.956 \AA)$ interaction between sulphinate oxygen and $\mathrm{B}-\mathrm{OH}$ moiety. The more downfield shifted resonance of B-OH (10.74 ppm) in solution state ${ }^{1} \mathrm{H}$ NMR clearly indicates that the intramolecular interaction also persists in solution state (see Supporting Information Figure S2).

Reaction of $2\left(\mathbf{S}_{\mathbf{P}}, \mathbf{S}_{\mathbf{S}}\right)$ with $t$-BuLi in THF at $-78^{\circ} \mathrm{C}$ generates chiral lithioferrocene, which was trapped with $\mathrm{PPh}_{2} \mathrm{Cl}$ to give compound $4\left(\mathbf{S}_{\mathbf{P}}\right)$. The ${ }^{1} \mathrm{H}$ NMR spectrum shows three signals at $\delta=4.66$ (dd), 4.26 (pseudo triplet), and $4.07 \mathrm{ppm}$ (dd), as expected for a 1,2-disubstituted $\mathrm{Cp}$ ring, and a singlet at $\delta=4.18 \mathrm{ppm}$ for the free $\mathrm{Cp}$ ring. A signal at $77.6 \mathrm{ppm}$ in the ${ }^{11} \mathrm{~B}$ NMR spectrum confirms that $\mathrm{BMes}_{2}$ is intact and a resonance at $\delta=-20.5 \mathrm{ppm}$ in the ${ }^{31} \mathrm{P}$ NMR spectrum confirms the attachment of $\mathrm{PPh}_{2}$. The appearance of protonated molecular ion $[\mathrm{M}+\mathrm{H}]^{+}$peak at 619 in the ESI mass spectrum confirms the formation of $\mathbf{4}\left(\mathbf{S}_{\mathbf{P}}\right)$. The ${ }^{11} \mathrm{~B}$ and ${ }^{31} \mathrm{P}$ resonances clearly indicate the presence of unquenched tricoordinated phosphine and borane centres in $\mathbf{4}\left(\mathbf{S}_{\mathbf{P}}\right)$ in solution. ${ }^{1-3,14}$ The optical purity of $\mathbf{4}\left(S_{\mathbf{P}}\right)$ was confirmed by single crystal X-ray analysis and optical rotation studies. Compound $\mathbf{5}\left(\mathbf{S}_{\mathbf{P}}\right.$, $\mathbf{S}_{\mathbf{S}}$ ) was prepared by adopting known literature ${ }^{15 \mathrm{~d}}$ procedure (scheme 1). Compound $\mathbf{4}\left(\mathbf{R}_{\mathrm{P}}\right)$ was prepared from $\mathbf{5}\left(\mathbf{S}_{\mathbf{P}}, \mathbf{S}_{\mathbf{S}}\right)$ following a procedure similar to that used for $\mathbf{4}\left(\mathbf{S}_{\mathbf{P}}\right)$. Compound $\mathbf{4}\left(\mathbf{R}_{\mathrm{P}}\right)$ was characterized by multinuclear NMR $\left({ }^{1} \mathrm{H},{ }^{13} \mathrm{C},{ }^{11} \mathrm{~B}\right.$ and $\left.{ }^{31} \mathrm{P}\right)$, ESI mass, optical rotation, and elemental analysis and UV-Vis spectroscopy. ${ }^{1} \mathrm{H}$ NMR integration and molecular ion peak in ESI Mass spectrum confirms the formation of $\mathbf{4}\left(\mathbf{R}_{\mathbf{P}}\right)$ and are consistent with $\mathbf{4}\left(\mathbf{S}_{\mathbf{P}}\right)$. The ${ }^{11} \mathrm{~B}(77.2 \mathrm{ppm})$ and ${ }^{31} \mathrm{P}(-20.5 \mathrm{ppm})$ resonances are also in the range of free tricoordinated phosphine and borane, respectively. ${ }^{1-3}$

Molecular structure of compounds $2\left(\mathbf{S}_{\mathrm{P}}, \mathbf{S}_{\mathrm{S}}\right), \mathbf{3}\left(\mathbf{S}_{\mathrm{P}}\right.$, $\left.\mathbf{S}_{\mathbf{S}}\right), \mathbf{4}\left(\mathbf{S}_{\mathbf{P}}\right)$ and $\mathbf{5}\left(\mathbf{S}_{\mathbf{P}}, \mathbf{S}_{\mathbf{S}}\right)$ are confirmed by single crystal X-ray diffraction studies. The molecular structures are shown in figure 1 with important geometric parameters. Recently, Aldrige and co-workers ${ }^{14}$ reported the crystal structure of $\mathbf{2}\left(\mathbf{S}_{\mathbf{P}}, \mathbf{S}_{\mathbf{S}}\right)$ and $\mathbf{3}\left(\mathbf{S}_{\mathbf{P}}, \mathbf{S}_{\mathbf{S}}\right)$, but the inter and intramolecular bonding parameters vary considerably in the present report. In addition, the synthetic procedure for these compounds reported in the present study is different from the literature. The dihedral angle between $\mathrm{BC} 2 / \mathrm{BCO}$ plane and plane of substituted $\mathrm{Cp}$ ring is considerably smaller for $\mathbf{4}\left(\mathbf{S}_{\mathbf{P}}\right)$ with $11.7^{\circ}$ in comparison to the highly tilted $\mathbf{2}\left(\mathbf{S}_{\mathbf{P}}, \mathbf{S}_{\mathbf{S}}\right),\left(59.2^{\circ}\right)$, while the angle found for $\mathbf{3}\left(\mathbf{S}_{\mathbf{P}}, \mathbf{S}_{\mathbf{S}}\right)$ lies in between at $27.7^{\circ}$ (table 2). This might be due to the steric bulk of mesityl substituents in $\mathbf{2}\left(\mathbf{S}_{\mathbf{P}}, \mathbf{S}_{\mathrm{S}}\right)$, and $\mathbf{4}\left(\mathbf{S}_{\mathbf{P}}\right)$. Steric effects are also evident from a comparison of the $\mathrm{Cp} / / \mathrm{Cp}$ tiltangles of $\mathbf{2}\left(\mathbf{S}_{\mathbf{P}}, \mathbf{S}_{\mathbf{S}}\right) \mathbf{- 5}\left(\mathbf{S}_{\mathbf{P}}, \mathbf{S}_{\mathrm{S}}\right)$, which for $\mathbf{4}\left(\mathbf{S}_{\mathbf{P}}\right)$ is $8.6^{\circ}$, whereas for $\mathbf{2}\left(\mathbf{S}_{\mathbf{P}}, \mathbf{S}_{\mathbf{S}}\right), \mathbf{3}\left(\mathbf{S}_{\mathbf{P}}, \mathbf{S}_{\mathbf{S}}\right)$ and $\mathbf{5}\left(\mathbf{S}_{\mathbf{P}}, \mathbf{S}_{\mathbf{S}}\right)$ they are 4.32 , 1.18 and $3.19^{\circ}$, respectively. $\mathbf{3}\left(\mathbf{S}_{\mathbf{P}}, \mathbf{S}_{\mathbf{S}}\right)$ shows more pronounced $\mathrm{Fe}-\mathrm{B}$ interaction $(3.214 \AA)$ compared to $\mathbf{2}\left(\mathbf{S}_{\mathbf{P}}\right.$, $\left.\mathbf{S}_{\mathbf{S}}\right)(3.44 \AA)$ and $\mathbf{4}\left(\mathbf{S}_{\mathbf{P}}\right)(3.36 \AA)$. This can be rationa-

Table 2. Selected intramolecular interactions (distance $(\AA)$ and angles $\left(^{\circ}\right)$ ) involved in $\mathbf{2}\left(\mathbf{S}_{\mathbf{P}}, \mathbf{S}_{\mathbf{S}}\right), \mathbf{3}\left(\mathbf{S}_{\mathbf{P}}, \mathbf{S}_{\mathbf{S}}\right), \mathbf{4}\left(\mathbf{S}_{\mathbf{P}}\right)$, and $\mathbf{5}\left(\mathbf{S}_{\mathbf{P}}\right.$, $\mathbf{S}_{\mathbf{S}}$.

\begin{tabular}{lcccc}
\hline Compound & $\mathbf{2}\left(\mathbf{S}_{\mathbf{P}}, \mathbf{S}_{\mathbf{S}}\right)$ & $\mathbf{3}\left(\mathbf{S}_{\mathbf{P}}, \mathbf{S}_{\mathbf{S}}\right)$ & $\mathbf{4}\left(\mathbf{S}_{\mathbf{P}}\right)$ & $\mathbf{5}\left(\mathbf{S}_{\mathbf{P}}, \mathbf{S}_{\mathbf{S}}\right)$ \\
\hline $\mathrm{Cp} / / \mathrm{Cp}$ & 4.32 & 1.18 & 8.61 & 3.19 \\
$\mathrm{BC} 2 / \mathrm{BCO} / / \mathrm{Cp}$ & 59.23 & 27.74 & 11.73 & - \\
$\mathrm{Fe}-\mathrm{B}$ & 3.442 & 3.214 & 3.369 & - \\
\hline
\end{tabular}




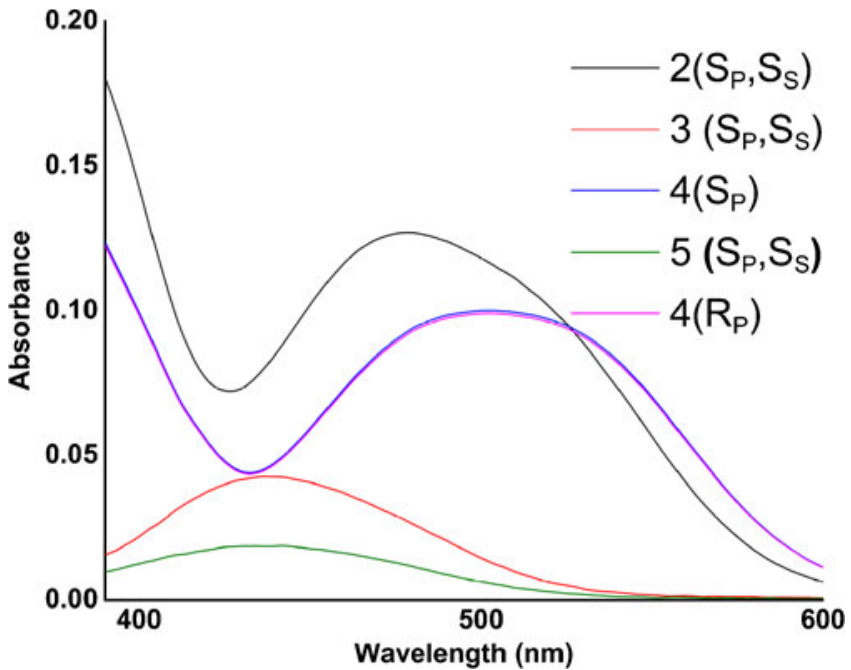

Figure 2. Uv-Vis spectra of $\mathbf{2}\left(\mathbf{S}_{\mathbf{P}}, \mathbf{S}_{\mathbf{S}}\right), \mathbf{3}\left(\mathbf{S}_{\mathbf{P}}, \mathbf{S}_{\mathbf{S}}\right), \mathbf{4}\left(\mathbf{S}_{\mathbf{P}}\right)$, $\mathbf{4}\left(\mathbf{R}_{\mathbf{P}}\right)$ and $\mathbf{5}\left(\mathbf{S}_{\mathbf{P}}, \mathbf{S}_{\mathbf{S}}\right)$.

lized by the electronic factor. The boron centre in $\mathbf{3}\left(\mathbf{S}_{\mathbf{P}}\right.$, $\mathbf{S}_{\mathbf{S}}$ ), (connected with $\mathrm{OH}$ and one mesityl group, respectively) is more electron deficient than in $\mathbf{2}\left(\mathbf{S}_{\mathbf{P}}, \mathbf{S}_{\mathbf{S}}\right)$ and $\mathbf{4}\left(S_{\mathbf{P}}\right)$ (connected with two mesityl groups).

The boron centre in $\mathbf{3}\left(\mathbf{S}_{\mathbf{P}}, \mathbf{S}_{\mathbf{S}}\right)$, and $\mathbf{4}\left(\mathbf{S}_{\mathbf{P}}\right)$ is planar with the sum of angle around boron is $360^{\circ}$, in the case of $2\left(\mathbf{S}_{\mathbf{P}}, \mathbf{S}_{\mathbf{S}}\right)$ little pyramidalization occurred. ${ }^{14}$ The PB separation of $3.567 \AA$ in solid state together with ${ }^{11} \mathrm{~B}$ and ${ }^{31} \mathrm{P}$ resonances (vide supra) in solution state clearly indicates the presence of an unquenched PCFLP in both forms. The electronic structure of compounds $2\left(\mathbf{S}_{\mathbf{P}}, \mathbf{S}_{\mathrm{S}}\right)$ $-\mathbf{5}\left(\mathbf{S}_{\mathbf{P}}, \mathbf{S}_{\mathrm{S}}\right)$ has been studied by UV-Vis spectroscopy (figure 2). The longest wavelength absorption has been observed for $\mathbf{4}\left(\mathbf{S}_{\mathbf{P}}\right)$ and $\mathbf{4}\left(\mathbf{R}_{\mathbf{P}}\right)$, followed by $\mathbf{2}\left(\mathbf{S}_{\mathbf{P}}, \mathbf{S}_{\mathrm{S}}\right)$, $\mathbf{3}\left(\mathbf{S}_{\mathbf{P}}, \mathbf{S}_{\mathbf{S}}\right)$ and $\mathbf{5}\left(\mathbf{S}_{\mathbf{P}}, \mathbf{S}_{\mathbf{S}}\right)$ (figure 2). This band can be attributed to a $\mathrm{d}-\mathrm{d}$ transition of the ferrocene moiety with considerable charge-transfer character. ${ }^{13}$ The particular order may suggest that electronic interactions between the d-orbitals of the ferrocenyl and the empty $p$-orbital on boron are promoted by sterically bulky substituents on boron.

\section{Conclusions}

In conclusion, the novel planar chiral Lewis acids $\mathbf{3}\left(\mathbf{S}_{\mathbf{P}}, \mathbf{S}_{\mathbf{S}}\right)$, 1-phosphino-2-borylferrocenes $\mathbf{4}\left(\mathbf{S}_{\mathbf{P}}\right)$ and 2phosphino-1-borylferrocenes $\mathbf{4}\left(\mathbf{R}_{\mathbf{P}}\right)$ are readily accessible from ferrocene sulphinate precursor. Adopting a simple synthetic approach and a single precursor, we have synthesized enentiomerically pure $S_{P}$ and $R_{P}$ isomers. We are currently investigating the catalytic properties of compounds $\mathbf{3}\left(\mathbf{S}_{\mathbf{S}}\right), \mathbf{4}\left(\mathbf{S}_{\mathbf{P}}\right)$ and $\mathbf{4}\left(\mathbf{R}_{\mathbf{P}}\right)$. We are also trying to replace the mesityl groups on boron with other electron deficient groups like pentafluorophenyl and 1,3,5-trifluoromethylphenyl to fine tune the Lewis acidity of boron centre and to set-up a general route to enantiomerically pure Planar Chiral Frustrated Lewis Pairs (PCFLP's).

\section{Supporting information}

${ }^{1} \mathrm{H}$ NMR and ${ }^{13} \mathrm{C}$ NMR, ${ }^{11} \mathrm{~B}$ and ${ }^{31} \mathrm{P}$ spectra and HRMS of compounds $2\left(\mathbf{S}_{\mathrm{P}}, \mathbf{S}_{\mathrm{S}}\right), \mathbf{3}\left(\mathbf{S}_{\mathrm{P}}, \mathbf{S}_{\mathrm{S}}\right), \mathbf{4}\left(\mathbf{S}_{\mathbf{P}}\right)$, $\mathbf{4}\left(\mathbf{R}_{\mathbf{P}}\right)$ and $\mathbf{5}\left(\mathbf{S}_{\mathbf{P}}, \mathbf{S}_{\mathbf{S}}\right)$. CCDC 823721 - 823724 contain the supplementary crystallographic data for this paper. These data can be obtained free of charge from The Cambridge Crystallographic Data Centre via www.ccdc.cam.ac.uk/data_request/cif.

Supplementary figures S1-S13 are given as supplementary material (see www.ias.ac.in/chemsci).

\section{Acknowledgements}

This work was supported by the Department of Science and Technology (DST), New Delhi, India and Indian Institute of Science (IISc), Bangalore. PS thanks IISc, Bangalore for research fellowship.

\section{References}

1. a) Gerhard Erker 2011 Dalton Trans. 40 7475; b) Dureen M A, Brown C C and Stephan D W 2010 Organometallics 29 6594; c) Dureen M A, Brown C C and Stephan D W 2010 Organometallics 29 6622; d) Morton J, Dureen M A and Stephan D W 2010 Chem. Commun. 46 8947; e) Ullrich M, Lough A J and Stephan D W 2010 Organometallics 29 3647; f) Birkmann B, Voss T, Geier S J, Ullrich M, Kehr G, Erker G and Stephan D W 2010 Organometallics 29 5310; g) Neu R C, Ouyang E Y, Geier S J, Zhao X, Ramos A and Stephan D W 2010 Dalton Trans. 39 4285; h) Voss T, Chen C, Erker G and Stephan D W 2010 Chem. Eur. J. 16 3005; i) Axenov K V, Momming C M, Kehr G, Fröhlich R and Erker G 2010 Chem. Eur. J. 16 14069; j) Grimme S, Kruse H, Goerigk L and Erker G 2010 Angew. Chem. Int. Ed. 49 1402; k) Schirmer B and Grimme S 2010 Chem. Commun. 46 7942; 1) Ullrich M, Seto K S-H, Alan J Lough and Stephan D W 2009 Chem. Commun. 2335; m) Ramos A, Lough A and Stephan D W 2009 Chem. Commun. 1118; n) Ullrich M, Lough A J and Stephan D W 2009 J. Am. Chem. Soc. 131 52; o) Spies P, Kehr G, Bergander K, Wibbeling B, Frohlich R and Erker G 2009 Dalton Trans. 1534; p) Privalov T 2009 Dalton Trans. 1321; q) Rokob T A, Hamza A, Stirling A and Papai I 2009 J. Am. Chem. Soc. 131 2029; r) Privalov T 2009 Eur. J. Inorg. Chem. 2229; s) Guo Y and Li S 2009 Eur. J. Inorg. Chem. 2229; t) Geier S, Gilbert T M and Stephan D W 2008 J. Am. Chem. Soc. 13012638

2. Welch G C, San Juan R, Masuda J D and Stephan D W 2006 Science 3141124 
3. a) Schwendemann S, Tumay T A, Axenov K V, Peuser I, Kehr G, Frohlich R and Erker G 2010 Organometallics 29 1067; b) Voss T, Chen C, Kehr G, Nauham E, Erker G and Stephan D W 2010 Chem. Eur. J. 16 3005; c) Ramos A, Lough A J and Stephan D W 2009 Chem. Commun. 1118; d) Huber D P, Kehr G, Bergander K, Frohlich R, Erker G, Tanino S, Ohki Y and Tatsumi K 2008 Organometallics 27 5279; e) Tebben L, Bussmann K, Hegemann M, Kehr G, Frohlich R and Erker G 2008 Organometallics 27 4269; f) Liptau P, Neumann M, Erker G, Kehr G, Frohlich R and Grimme S 2004 Organometallics 23 21; g) Chen D, Klankermayer J 2008 Chem. Commun. 2130-2131; h) Chen D, Wang Y and Klankermayer J 2010 Angew. Chem. Int. Ed. 499475

4. a) Yamamoto H 2000 Lewis acids in organic synthesis Wiley-VCH, Weinheim; b) Piers W E, Irvine G J and Williams V C 2000 Eur. J. Inorg. Chem. 2131; c) Chen E Y-X and Marks T J 2000 Chem. Rev. 100 1391; d) Piers WE 2004 Adv. Organomet. Chem. 52 1; e) Ishihara K 2000 Lewis acids in organic synthesis, Vol. 1 (Ed.: Yamamoto H), Wiley-VCH, Weinheim, p. 135; Vol. 1, p. 135; f) Brown H C and Ramachandran P V 1995 J. Organomet. Chem. 500 1; g) Dhokte U P, Soundararajan R, Ramachandran P V and Brown H C 1996 Tetrahedron Lett. 37 8345; h) Dhotke U P and Brown H C 1998 Organometallics 17 2891; e) Payette J N and Yamamoto H 2009 Angew. Chem., Int. Ed. 48 8060; f) Li P F and Yamamoto H 2009 J. Am. Chem. Soc. 131 16628; g) Payette J and Yamamoto H 2007 J. Am. Chem. Soc. 1299536

5. a) Ramachandran P V, Padiya K J, Rauniyar V, Reddy M V R and Brown H C 2004 Tetrahedron Lett. 45 1015; b) Ramachandran P V, Prabhudas B, Chandra J S, Reddy M V R and Brown H C 2004 Tetrahedron Lett. 45 1011; c) Salunkhe A M, Ramachandran P V and Brown H C 2002 Tetrahedron 58 10059; d) Ramachandran P V, Zou M F and Brown H C 2002 Helv. Chim. Acta. 85 3027; e) Ramachandran P V, Brown H C and Pitre S 2002 J. Org. Chem. 67 5315; f) Ramachandran P V, Brown H C and Pitre S 2001 Org. Lett. 317

6. a) Hernandez E, Canales E, Gonzalez E and Soderquist J A 2006 Pure Appl. Chem. 7 1389; b) Soderquist J A, Kock I, Estrella M E 2006 Org. Proc. Res. Dev. 10, 1076; c) Gonzalez A Z and Soderquist J A 2007 Org. Lett. 9 1081; d) Canales E, Gonzalez A Z and Soderquist J A 2007 Angew. Chem. Int. Ed. Engl. 46(3) 397; e) Hernandez E, Burgos C H, Alicea E and Soderquist J A 2006 Org Lett. 8(18) 4089; f) Gonzalez A Z, Canales E and Soderquist J A 2006 Org Lett. 8(15) 3331; g) Canales E, Hernandez E and Soderquist J A 2006 J. Am. Chem. Soc. 128(27) 8712

7. a) Fan C, Mercier L G, Piers W E and Parvez M 2010 J. Am. Chem. Soc. 132 9604; b) Berkefeld A, Piers W E and Parvez M 2010 J. Am. Chem. Soc. 132 10660; c) Piers W E, Bourke S C and Conroy K C 2004 Angew. Chem. Int. Ed. 44 5016; d) Lewis S P, Taylor N J, Piers W E and Collins S 2003 J. Am. Chem. Soc. 125 14686; e) Morrison D J and Piers W E 2003 Org. Lett. 5 2857; f) Blackwell J M, Morrision D J and Piers W E 2002 Tetrahedron 58 8247; g) Blackwell J M, Piers W E and McDonald R 2002 J. Am. Chem. Soc. 1241295
8. Boshra R, Doshi A and Jäkle F 2008 Angew. Chem Int. Ed. 471134

9. a) Fu G C 2006 Acc. Chem. Res. 39 853; b) Colacot T J 2003 Chem. Rev. 103 3101; c) Gabbai F P 2003 Angew. Chem. 115 2318; 2003 Angew. Chem. Int. Ed. 42 2218; d) Guillaneux D, Martiny L and Kagan H B 2000 Coll. Czech. Chem. Commun. 65 717; e) Argouarch G, Samuel O and Kagan H B 2000 Eur. J. Org. Chem. 2885

10. a) Cui C, Heilmann-Brohl J, Sánchez Perucha A, Thomson M D, Roskos H G, Wagner M and Jäkle F 2010 Macromolecules 43 5256; b) Scholz S, Scheibitz M, Schödel F, Bolte M, Wagner M and Lerner H-W 2007 Inorg. Chim. Acta. 360 3323; c) Scheibitz M, Bats J W, Bolte M, Lerner H-W and Wagner M 2004 Organometallics 23 940; d) Scheibitz M, Bats J W, Bolte M and Wagner M 2003 Eur. J. Inorg. Chem. 2049; e) Ma K, Scheibitz M, Scholz S and Wagner M 2002 J. Organomet. Chem. $\mathbf{6 5 2} 11$

11. a) Day J K, Bresner C, Coombs N D, Fallis I A, Ooi L-L, Harrington R W, Clegg W and Aldridge S 2008 Inorg. Chem. 47 793; b) Broomsgrove A E J, Addy D, Bresner C, Fallis I A, Thompson A L and Aldridge S 2008 Chem. Eur. J. 14 7525; c) Vidovic D, Pierce G A and Aldridge S 2009 Chem. Commun. 1157; d) Broomsgrove A E J, Addy D, Di Paolo A, Morgan I R, Bresner C, Chislett V, Fallis I A, Thompson A L, Vidovic D and Aldridge S 2010 Inorg. Chem. 49 157; e) Wade C R, Broomsgrove A E J, Aldridge S and Gabbaï F P 2010 Chem. Rev. 110 3958

12. a) Chen J, Venkatasubbaiah K, Pakkirisamy T, Doshi A, Yusupov A, Patel Y, Lalancette R A and Jäkle F 2010 Chem. Eur. J. 16 8861; b) Boshra R, Venkatasubbaiah K, Doshi A and Jäkle F 2009 Organometallics 28 4141; c) Venkatasubbaiah K, Pakkirisamy T, Doshi A, Lalancette R A and Jäkle F 2008 Dalton Trans. 4507; d) Boshra R, Venkatasubbaiah K, Doshi A, Lalancette R A, Kakalis L and Jäkle F 2007 Inorg. Chem. 46 10174; e) Venkatasubbaiah K, Nowik I, Herber R H and Jäkle F 2007 Chem. Commun. 2165; f) Venkatasubbaiah K, Bats J W, Rheingold A L and Jäkle F 2005 Organometallics 24 6043; g) Venkatasubbaiah K, Zakharov L N, Kassel W S, Rheingold A L and Jäkle F 2005 Angew. Chem. Int. Ed. 44 5428; h) Boshra R, Sundararaman A, Zakharov L N, Incarvito C D, Rheingold A L and Jäkle F 2005 Chem. Eur. J. 11 2810; i) Gamboa J A, Sundararaman A, Kakalis L, Lough A J and Jäkle F 2002 Organometallics 214169

13. a) Morgan I R, Di Paolo A, Vidovic D, Fallis I A and Aldridge S 2009 Chem. Commun. 7288; b) Thilagar $\mathrm{P}$ and Sudagar P 2010 Poster No.25, presented at the symposium on Frontiers in Main-Group and Organometallic Chemistry (NSFMOC)' Indian institute of Science, Bangalore, November 20, 2010; c) Thilagar P and Sudagar P 2011 Poster No.19, presented at the 13th CRSI National Symposium in Chemistry \& 5th CRSI-RSC Symposium in Chemistry,National Institute of Science Education and Research (NISER),bhubeneshwer, February 4-6; d) Thilagar P and Sudagar P 2011 Pp-31, presented at the 3rd Asian Conference on Coordination Chemistry (ACCC-3),October 17-20; e) Siewert I, Vidovic D and Aldridge S J 2011 Organomet. Chem. 6962528 
14. a) Rehipre F, Samuel O and Kagan H B 1990 Tetrahedron Lett. 31(22) 3121; b) Pre F R, Riant O, Ricard L and Kagan H B 1993 Angew. Chem. Int. Ed. Eng. 32(4) 568; c) Argouarch G, Samuel O, Riant O, Daran J-C and Kagan H B 2000 Eur. J. Org. Chem. 2893; d) Riant, Gilles Argouarch, Denis Guillaneux, Odile Samuel and Henri B Kagan 1998 J. Org. Chem. 633511
15. a) Bruker Analytical X-ray Systems. SMART: Bruker Molecular Analysis Research Tool, Version 5.618; Bruker AXS: Madison, WI, 2000; b) Bruker Analytical X-ray Systems. SAINT-NT, Version 6.04; Bruker AXS: Madison, WI, 2001. C) Bruker Analytical X-ray Systems. SHELXTL-NT, Version 6.10 